\title{
Yield Targeting for Rice under SRI on Alfisols of Tamil Nadu through Soil Test based Integrated Plant Nutrition System
}

\author{
S. Maragatham ${ }^{\text {** }}$, R. Santhi ${ }^{2}$, K.M. Sellamuthu ${ }^{2}$ and Pradip Dey ${ }^{3}$
}

${ }^{1}$ Agricultural College and Research Institute, Kudumiyanmalai, Pudukkottai, TNAU, India

${ }^{2}$ All India Coordinated Research Project for Soil Test Crop Response Correlation (AICRP-

STCR), Department of Soil Science and Agricultural Chemistry

Tamil Nadu Agricultural University, Coimbatore - 641 003, Tamil Nadu, India

${ }^{3}$ AICRP-STCR, Indian Institute of Soil Science (IISS), Bhopal, India

*Corresponding author

\section{A B S T R A C T}

Soil Test Crop Response studies involving Integrated Plant Nutrition System (STCR IPNS) were conducted on a Typic Haplustalf of Tamil Nadu, Southern India for developing

\section{Keywords}

Fertiliser

prescription

equations, Rice,

SRI, Soil test crop

response, Targeted yield

\section{Article Info}

Accepted:

08 July 2018

Available Online:

10 August 2018 fertiliser prescriptions for desired yield targets of rice- rice sequence under System of Rice Intensification (SRI). By adopting the Inductive cum Targeted yield model, variations in soil fertility with reference to soil available nitrogen $(\mathrm{N})$, phosphorus $(\mathrm{P})$ and potassium $(\mathrm{K})$ were established and test crop experiment was conducted with rice-rice sequence. The findings pertaining to rabi season is discussed in this paper. From the field experimental data, nutrient requirement (NR), contribution of nutrients from soil (Cs), fertilizer (Cf) and farmyard manure (Cfym) were computed. The nutrient requirement for producing one quintal of rice grain yield was worked out as $1.50 \mathrm{~kg}$ of $\mathrm{N}, 0.68 \mathrm{~kg}$ of $\mathrm{P}_{2} \mathrm{O}_{5}$ and $1.97 \mathrm{~kg}$ of $\mathrm{K}_{2} \mathrm{O}$. The contributions of available $\mathrm{N}, \mathrm{P}_{2} \mathrm{O}_{5}$ and $\mathrm{K}_{2} \mathrm{O}$ towards total $\mathrm{N}, \mathrm{P}$ and $\mathrm{K}$ uptake by rice from soil and fertilizer were 16.14, 38.40, 16.57 and 35.70, 33.17, 60.17 per cent respectively while the contribution from manure was 24.24, 9.52 and 33.89 per cent respectively. The estimated per cent contribution of $\mathrm{N}, \mathrm{P}_{2} \mathrm{O}_{5}$ and $\mathrm{K}_{2} \mathrm{O}$ from FYM (Cfym) was 24.26, 9.52 and 33.89 per cent respectively. Using the basic parameters, fertiliser prescription equations were developed for rabi season and ready reckoner of fertiliser doses were formulated. The contribution of FYM@12.5 $\mathrm{t} \mathrm{ha}^{-1}$ when applied along with recommended doses of NP\&K fertilisers was found to be 40, 20 and $32 \mathrm{~kg} \mathrm{ha}^{-1}$ of fertiliser $\mathrm{N}, \mathrm{P}_{2} \mathrm{O}_{5}$ and $\mathrm{K}_{2} \mathrm{O}$ respectively.

\section{Introduction}

Rice, a global grain is the king crop of Asia and staple food grain for more than half of the world population. The demand for rice is expected to rise due to increase in population and reduction in area under rice cultivation in next $15-20$ years. Water scarcity appears to be one of the major constraints affecting rice production across the globe. More than 80 percent of the fresh water resources in Asia are used for agriculture and about a half of it is 
used for rice production (Mahender Kumar et al., 2013). Available estimates indicate that fresh water availability in India will be reduced to one-third by 2025 . Hence, producing more rice for every drop of water, as well as with less land and minimum fertilizer if possible, is important for sustainability of rice production systems. System of Rice Intensification (SRI) is such holistic agro ecological crop management technique seeking alternatives to the conventional high input oriented agriculture, through effective integration of crop, soil, water and nutrient. This methodology increases the productivity of irrigated rice by changing the management of plants, soil, water and nutrients resulting in both healthy soil and plants, supported by greater root growth and the soil microbial abundance and diversity.

Fertilizer is one of the inputs which bring quantum jump in the yield of rice. The nutrient uptake by rice plant is different from other field crops. To improve the production efficiency of rice and to synchronize the application of nutrients with the demand of the plant, it is necessary to apply required dose of NPK fertilizers. Further, the Indian agriculture is operating on a net negative balance of 8-10 mt of NPK per annum. Use of fertilizers by the farmers without information on soil fertility status and nutrient requirement by the crop result in adverse effect on soil and crop either by nutrient toxicity or deficiency. In this context, soil test based fertilizer recommendation plays a vital role in ensuring balanced nutrition to crops and also in preventing wasteful expenditure on the use of costly fertilizer.

At this juncture, Inductive cum Targeted yield model provides a scientific basis for balanced fertilization and balance between applied nutrients and soil available nutrients. Addition of Integrated Plant Nutrition System (IPNS) to this concept ensures balanced fertilization by application of inorganic and organic sources of nutrients. Keeping the above points in view the present investigation was contemplated adopting the Inductive cum Targeted Yield model so as to develop basic data of nutrient requirement and contribution of nutrients to total uptake from different sources and to develop fertilizer $\mathrm{N}, \mathrm{P}$ and $\mathrm{K}$ prescription equations and farmer friendly ready reckoner to prescribe fertilizers in rice crop under SRI for rabi season on an Alfisol.

\section{Materials and Methods}

\section{Basic concept}

The methodology adopted in this study is the prescription procedure outlined by Truog (1960) and modified by Ramamoorthy et al., (1967) as "Inductive cum Targeted yield model" which provides a scientific basis for balanced fertilization and balance between applied nutrients and soil available nutrients forms.

Operational range of variation in soil fertility was created deliberately to generate data covering appropriate range of values for each controllable variable (fertilizer dose) at different levels of uncontrollable variable (soil fertility) which could not be expected to occur at one place normally. Hence, in order to create fertility variations in the same field, a gradient experiment was conducted prior to the test crop experiment to reduce the heterogeneity in the soil population studied, management practices adopted and climatic conditions prevailing.

After confirming the creation of soil fertility gradients, test crop experiment was conducted for developing fertilizer prescription. In Tamil Nadu, STCR-IPNS (Integrated Plant Nutrition System) recommendations have been developed for 29 crops comprising cereals, millets, pulses, oilseeds, sugarcane, cotton, vegetables, spices and medicinal crops on 16 soil series (Santhi et al., 2017). 


\section{Soil characteristics}

The field experiments were conducted at the wetland of wetlands farm, TNAU Coimbatore, Tamil Nadu on Noyyal soil series (Clay loamy, mixed isohyperthermic, Typic Haplustalf) belongs to Alfisol. The soil was clay loam in texture, moderately alkaline in reaction ( $\mathrm{pH}$ 8.2) and non - saline (EC $0.49 \mathrm{dS} \mathrm{m}^{-1}$ ). The initial soil fertility status showed low available $\mathrm{N}\left(250 \mathrm{~kg} \mathrm{ha}^{-1}\right.$, medium available $\mathrm{P}\left(19.9 \mathrm{~kg} \mathrm{ha}^{-1}\right)$ and high available $\mathrm{K}(560$ $\left.\mathrm{kg} \mathrm{ha}^{-1}\right)$. The available $\mathrm{Zn}$ and $\mathrm{Cu}$ were in the deficient status $\left(0.63\right.$ and $0.33 \mathrm{mg} \mathrm{kg}^{-1}$ respectively) while available $\mathrm{Mn}$ and $\mathrm{Fe}$ were in the sufficient status (5.52 and $11.27 \mathrm{mg} \mathrm{kg}^{-1}$ ).

\section{Treatments and soil and plant analysis}

The approved treatment structure and lay out design as followed in the All India Coordinated Research Project for Investigations on Soil Test Crop Response Correlation based on "Inductive cum Targeted yield model" was adopted in the present investigation. There were two phases of field experimentation viz., gradient and test crop experiment.

\section{Fertility gradient experiment}

To create operational range of variation in soil fertility, the experimental field was divided into three equal strips, $\mathrm{N}_{0} \mathrm{P}_{0} \mathrm{~K}_{0}$ (strip I), $\mathrm{N}_{1} \mathrm{P}_{1} \mathrm{~K}_{1}$ (strip II) and $\mathrm{N}_{2} \mathrm{P}_{2} \mathrm{~K}_{2}$ (strip III). $\mathrm{N}_{1}$ is the nitrogen dose equivalent to blanket recommendation for the gradient crop of rice. The $\mathrm{P}_{1}$ and $\mathrm{K}_{1}$ are the $\mathrm{P}$ and $\mathrm{K}$ fixing capacities of the soils respectively. The first strip received no fertiliser $\left(\mathrm{N}_{0} \mathrm{P}_{0} \mathrm{~K}_{0}\right)$, the second strip received $\mathrm{N}_{1}$ as blanket dose and $\mathrm{P}_{1}$ and $\mathrm{K}_{1}$ as $\mathrm{P}$ and $\mathrm{K}$ fixing capacities of the soil and the third strip received twice the dose of second strip and a gradient crop of rice (var.ADT 43) was grown. Eight pre-sowing and post-harvest soil samples were collected from each fertility strip and analysed for alkaline $\mathrm{KMnO}_{4}-\mathrm{N}$, Olsen -P and $\mathrm{NH}_{4} \mathrm{OAc}-\mathrm{K}$. At harvest, plant samples were collected, processed and analysed for N, P and $\mathrm{K}$ contents and NPK uptake was computed.

\section{Test crop experiment}

After confirming the establishment of fertility gradients in the experimental field, in the second phase of the field experiment, each strip was divided into 24 plots, and initial soil samples were collected from each plot and analysed for alkaline $\mathrm{KMnO}_{4}-\mathrm{N}$ (Subbiah and Asija, 1956), Olsen-P (Olsen et al., 1954) and $\mathrm{NH}_{4} \mathrm{OAc}-\mathrm{K}$ (Stanford and English, 1949). The experiment was laid out in a fractional factorial design comprising twenty four treatments and the test crop experiment with rice variety $\mathrm{CO}(\mathrm{R}) 49$ was conducted under SRI with four levels each of $\mathrm{N}(0,75,150$ and $\left.225 \mathrm{~kg} \mathrm{ha}^{-1}\right), \mathrm{P}_{2} \mathrm{O}_{5}\left(0,25,50\right.$ and $\left.75 \mathrm{~kg} \mathrm{ha}^{-1}\right)$ and $\mathrm{K}_{2} \mathrm{O}\left(0,25,50\right.$ and $\left.75 \mathrm{~kg} \mathrm{ha}^{-1}\right)$ and three levels of FYM $\left(0,6.25\right.$ and $\left.12.5 \mathrm{t} \mathrm{ha}^{-1}\right)$. The SRI practices were followed viz., planting of young seedlings, single seedling, wider spacing in a square pattern $(25 \times 25 \mathrm{~cm})$, intermittent irrigation, conoweeding with the aim of providing optimal growth conditions for the plant, to get better performance in terms of yield and input productivity. The experiment was conducted as per the approved guidelines of AICRP-STCR and fertiliser prescriptions were developed.

The IPNS treatments viz., NPK alone, NPK+ FYM @ $6.25 \mathrm{t} \mathrm{ha}^{-1}$ and NPK + FYM @ $12.5 \mathrm{t}$ $\mathrm{ha}^{-1}$ were superimposed across the strips. There were 21 fertiliser treatments along with three controls which were randomized in each strip in such a way that all the treatments occurred in both the directions. FYM was applied basally and fertiliser doses were imposed as per the 
treatments. Twenty five per cent of $\mathrm{N}$ and $\mathrm{K}_{2} \mathrm{O}$ and full dose of $\mathrm{P}_{2} \mathrm{O}_{5}$ were applied basally before transplantation and remaining $\mathrm{N}$ and $\mathrm{K}_{2} \mathrm{O}$ were applied in three equal splits viz., tillering, panicle initiation and heading stages. Routine agronomic practices were carried out periodically. The crop was grown to maturity, harvested and plot wise grain and straw yield were recorded. Plant and post-harvest soil samples were collected from each plot. The plant samples were processed and analyzed for $\mathrm{N}$ (Humphries, 1956), $\mathrm{P}$ and $\mathrm{K}$ contents
(Jackson, 1973) and NPK uptake by rice was computed using the drymatter yield.

Making use of the data on pre-sowing soil test values for available $\mathrm{N}, \mathrm{P}$ and $\mathrm{K}$, grain yield, total uptake of $\mathrm{N}, \mathrm{P}$ and $\mathrm{K}$, and doses of fertiliser $\mathrm{N}, \mathrm{P}_{2} \mathrm{O}_{5}$ and $\mathrm{K}_{2} \mathrm{O}$ applied, the basic parameters viz., nutrient requirement (NR), contribution of nutrients from soil (Cs), fertiliser (Cf) and farmyard manure (Cfym) were calculated as outlined by Ramamoorthy et al., (1967).

\section{i. Nutrient requirement (NR) $\mathrm{kg} \mathrm{q}^{-1}$}

$\mathrm{Kg} \mathrm{N} / \mathrm{P}_{2} \mathrm{O}_{5} / \mathrm{K}_{2} \mathrm{O}$ required per quintal of grain production

Total uptake of $\mathrm{N} / \mathrm{P}_{2} \mathrm{O}_{5} / \mathrm{K}_{2} \mathrm{O}\left(\mathrm{kg} \mathrm{ha}^{-1}\right)$

\section{ii. Per cent contribution of nutrients from soil to total nutrient uptake (Cs)}

Total uptake of $\mathrm{N} / \mathrm{P}_{2} \mathrm{O}_{5} / \mathrm{K}_{2} \mathrm{O}$ in control plot $\left(\mathrm{kg} \mathrm{ha}^{-1}\right)$

Per cent contribution of N/ $\mathrm{P}_{2} \mathrm{O}_{5} / \mathrm{K}_{2} \mathrm{O}$ from soil $=$

Soil test value for available $\mathrm{N} / \mathrm{P}_{2} \mathrm{O}_{5} / \mathrm{K}_{2} \mathrm{O}$ in control plot $\left(\mathrm{kg} \mathrm{ha}^{-1}\right)$

\section{iii. Per cent contribution of nutrients from fertiliser to total uptake (Cf)}

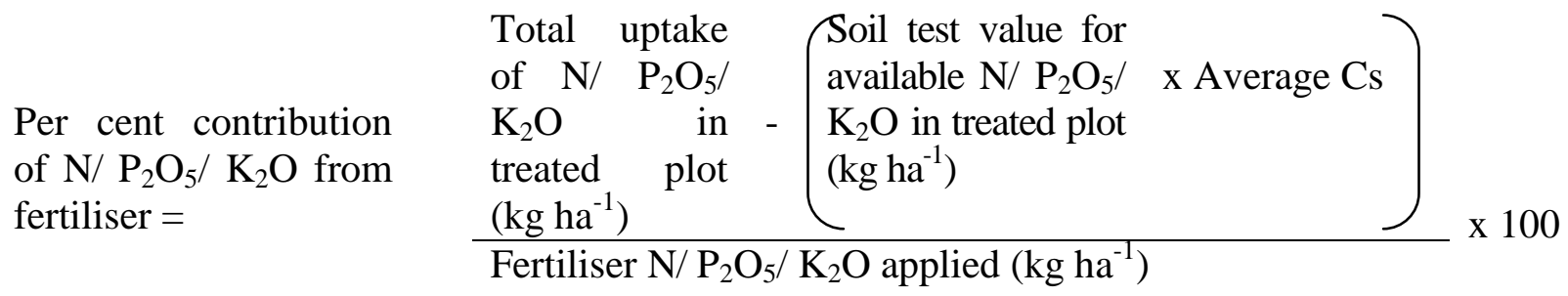

\section{iv. Percent contribution of nutrients from organic manure to total uptake (Co) Percent contribution from FYM (Cfym)}

$\left.\begin{array}{l}\text { Percent contribution of } \\ \text { N/P/K from FYM }=\begin{array}{l}\text { Total uptake } \\ \text { of N/P/K in } \\ \text { FYM treated } \\ \text { plot }\left(\mathrm{kg} \mathrm{ha}^{-1}\right)\end{array}\end{array} \quad \begin{array}{l}\text { Soil test value for } \\ \text { available N/P/K in x Average Cs } \\ \text { FYM treated plot } \\ \left(\mathrm{kg} \mathrm{h}^{-1}\right)\end{array}\right) \times 100$


These parameters were used for developing fertiliser prescription equations for deriving fertilisers doses, and the soil test based fertiliser recommendations were prescribed in the form of a ready reckoner for desired yield target of type rice under NPK alone and under IPNS.

\section{i) Fertiliser nitrogen (FN)}

$\mathrm{FN}=\frac{\mathrm{NR}}{\mathrm{Cf} / 100} \mathrm{~T}-\frac{\mathrm{Cs}}{\mathrm{Cf}} \mathrm{SN}$
$\mathrm{FN}=\frac{\mathrm{NR}}{\mathrm{Cf} / 100} \mathrm{~T}-\frac{\mathrm{Cs}}{\mathrm{Cf}} \mathrm{SN}-\frac{\mathrm{Cfym}}{\mathrm{C}_{\mathrm{f}}} \mathrm{ON}$

ii) Fertiliser phosphorus $\left(\mathrm{FP}_{2} \mathrm{O}_{5}\right)$

$$
\begin{aligned}
& \mathrm{FP}_{2} \mathrm{O}_{5}=\frac{\mathrm{NR}}{\mathrm{Cf} / 100} \mathrm{~T}-\frac{\mathrm{Cs}}{\mathrm{Cf}} \times 2.29 \times \mathrm{SP} \\
& \mathrm{FP}_{2} \mathrm{O}_{5}=\frac{\mathrm{NR}}{\mathrm{Cf} / 100} \mathrm{~T}-\frac{\mathrm{Cs}}{\mathrm{Cf}} \times 2.29 \times \mathrm{SP}-\frac{\mathrm{Cfym}}{\mathrm{C}_{\mathrm{f}}} \times 2.29 \times \mathrm{OP}
\end{aligned}
$$

iii) Fertiliser potassium $\left(\mathrm{FK}_{2} \mathrm{O}\right)$

$$
\begin{aligned}
& \mathrm{FK}_{2} \mathrm{O}=\frac{\mathrm{NR}}{\mathrm{Cf} / 100} \mathrm{~T}-\frac{\mathrm{Cs}}{\mathrm{Cf}} \times 1.21 \times \mathrm{SK} \\
& \mathrm{FK}_{2} \mathrm{O}=\frac{\mathrm{NR}}{\mathrm{Cf} / 100} \mathrm{~T}-\frac{\mathrm{Cs}}{\mathrm{Cf}} \times 1.21 \times \mathrm{SK}-\frac{\mathrm{Cfym}}{\mathrm{Cf}} \times 1.21 \times \mathrm{OK}
\end{aligned}
$$

where, $\mathrm{FN}, \mathrm{FP}_{2} \mathrm{O}_{5}$ and $\mathrm{FK}_{2} \mathrm{O}$ are fertiliser $\mathrm{N}$, $\mathrm{P}_{2} \mathrm{O}_{5}$ and $\mathrm{K}_{2} \mathrm{O}$ in $\mathrm{kg} \mathrm{ha}^{-1}$, respectively; $\mathrm{NR}$ is nutrient requirement $\left(\mathrm{N}\right.$ or $\mathrm{P}_{2} \mathrm{O}_{5}$ or $\left.\mathrm{K}_{2} \mathrm{O}\right)$ in $\mathrm{kg}$ $\mathrm{q}^{-1}, \mathrm{Cs}$ is per cent contribution of nutrients from soil, $\mathrm{Cf}$ is per cent contribution of nutrients from fertiliser, Cfym is percent contribution of nutrients from FYM, T is the yield target in $\mathrm{q} \mathrm{ha}^{-1} ; \mathrm{SN}, \mathrm{SP}$ and $\mathrm{SK}$ respectively are alkaline $\mathrm{KMnO}_{4}-\mathrm{N}$, Olsen-P and $\mathrm{NH}_{4} \mathrm{OAc}-\mathrm{K}$ in $\mathrm{kg} \mathrm{ha}^{-1}$ and $\mathrm{ON}$, OP and $\mathrm{OK}$ are the quantities of $\mathrm{N}, \mathrm{P}$ and $\mathrm{K}$ in $\mathrm{kg} \mathrm{ha}^{-1}$ supplied through FYM. These equations serve as a basis for predicting fertiliser doses for specific yield targets $(\mathrm{T})$ of rabi rice for varied soil available nutrient levels.

\section{Results and Discussion}

\section{Soil fertility status}

The data on initial soil test values of the test crop experiment revealed that, the mean $\mathrm{KMnO}_{4}-\mathrm{N}$ was 230, 262 and $296 \mathrm{~kg} \mathrm{ha}^{-1}$, respectively in strips I, II and III. The mean Olsen-P values were 18.0, 30, 3 and $38.5 \mathrm{~kg} \mathrm{ha}^{-1}$ respectively in strips I to III and the mean $\mathrm{NH}_{4} \mathrm{OAc}-\mathrm{K}$ values were 539, 588 and $620 \mathrm{~kg}$ $\mathrm{ha}^{-1}$ in strips I, II and III, respectively (Table 1). The per cent increase in soil available $\mathrm{N}$ of strip II over strip I was 13.9 and that of strip III over strip II and strip I were 13.0 and 28.7 respectively. Similarly, the respective per cent increase values for Olsen $-\mathrm{P}$ and $\mathrm{NH}_{4} \mathrm{OAc}-\mathrm{K}$ were 68.3, 27.1 and 113.9 and 9.1,5.4 and 15.0 respectively. In the present investigation, the existence of operational range of soil test values for available $\mathrm{N}, \mathrm{P}$ and $\mathrm{K}$ status was clearly depicted from the variation in initial soil available nutrient status which is a prerequisite and underlying principle for calculating the basic parameters and developing fertilizer prescription equations for calibrating the fertiliser doses for specific yield target of rice. Similar type of development of fertility gradient for the 
existence of operational range of available $\mathrm{N}$, $\mathrm{P}$ and $\mathrm{K}$ status was reported by reported by Mahajan et al., (2013) for wheat and Verma et al., (2017) for mustard. Due to the application of graded levels of fertilisers, notable fertility variations were recorded in various strips

\section{Grain yield and Nutrient Uptake}

The range and mean values (Table 2) indicated that the grain yield of rabi rice ranged from $2680 \mathrm{~kg} \mathrm{ha}^{-1}$ in strip I to $7440 \mathrm{~kg}$ $\mathrm{ha}^{-1}$ in strip III where the lowest yield was recorded in absolute control and the highest yield was recorded in $\mathrm{N}_{225} \mathrm{P}_{75} \mathrm{~K}_{75}+\mathrm{FYM} \mathrm{@}$ $12.5 \mathrm{t} \mathrm{ha}^{-1}$ with mean grain yield of 5156,5490 and $5733 \mathrm{~kg} \mathrm{ha}^{-1}$, respectively in strips I, II and III. The $\mathrm{N}$ uptake by rice varied from 39.0 to $120 \mathrm{~kg} \mathrm{ha}^{-1}$; $\mathrm{P}$ uptake from 6.2 to $24.7 \mathrm{~kg} \mathrm{ha}^{-1}$ and $\mathrm{K}$ uptake from 62 to $117 \mathrm{~kg} \mathrm{ha}^{-1}$. The total $\mathrm{N}, \mathrm{P}$ and $\mathrm{K}$ uptake was observed to be the highest in strip III followed by strip II and it was the least in strip I. Irrespective of the strips, NPK plus FYM @ $12.5 \mathrm{t} \mathrm{ha}^{-1}$ plots, the yield ranged from 3630 to $7440 \mathrm{~kg} \mathrm{ha}^{-1}$ with a mean of $6030 \mathrm{~kg} \mathrm{ha}^{-1}$ recording an increase of 115.4 per cent over absolute control. In NPK plus FYM @ $12.5 \mathrm{t} \mathrm{ha}^{-1}$ applied plots, the N, P and $\mathrm{K}$ uptake ranged from 52.8 to $126.0 ; 8.8$ to 23.7 and 69.8 to $117.0 \mathrm{~kg} \mathrm{ha}^{-1}$ with mean of 96.0, 18.4 and $96.3 \mathrm{~kg} \mathrm{ha}^{-1}$ respectively. The N, P and K uptake in NPK plus FYM @ $12.5 \mathrm{t} \mathrm{ha}^{-1}$ applied plots recorded an increase of 138.2, 76.9 and 47.4 per cent over absolute control and 82.1, 37.3 and 22.7 per cent over FYM alone @ $12.5 \mathrm{t}$ $\mathrm{ha}^{-1}$, respectively. The increased yield and uptake might be due to the improvement in physico-chemical properties of soil, solubilisation of native nutrients, supply of the nutrients in balanced amount and slow release of nutrients through integrated use of FYM. Similar, findings were reported by Antaryami Mishra et al., (2013) for rice tomato sequence and Saraswathi et al., (2015) in ragi.

\section{Basic parameters (Table 1)}

In the targeted yield model, the basic parameters for developing fertilizer prescription equations for rabi rice are nutrient requirement $(\mathrm{NR})$ in $\mathrm{kg}$ per quintal of grain yield, per cent contribution of available NPK from soil (Cs), fertilizers (Cf) and farmyard manure (Cfym). Making use of data on the grain yield of rice, total uptake of $\mathrm{N}, \mathrm{P}$ and $\mathrm{K}$, initial soil test values for available $\mathrm{N}, \mathrm{P}$ and $\mathrm{K}$ and doses of fertilizer $\mathrm{N}, \mathrm{P}_{2} \mathrm{O}_{5}$ and $\mathrm{K}_{2} \mathrm{O}$ applied, the basic parameters were computed.

\section{Nutrient requirement}

Nutrient requirement to produce one quintal $(100 \mathrm{kgs})$ of rice grain was $1.50 \mathrm{~kg}$ of $\mathrm{N}, 0.68$ $\mathrm{kg}$ of $\mathrm{P}_{2} \mathrm{O}_{5}$ and $1.97 \mathrm{~kg}$ of $\mathrm{K}_{2} \mathrm{O}$. Synchronized application of adequate amount of nutrients according to the demand of the plant is a prerequisite to improve the production efficiency of any crop. In rice crop, there was progressive increase in grain yield and nutrient uptake with the increased doses of applied $\mathrm{N}$, $\mathrm{P}_{2} \mathrm{O}_{5}$ and $\mathrm{K}_{2} \mathrm{O}$ and FYM. At the same time, application of nutrients especially major nutrients like $\mathrm{N}, \mathrm{P}$ and $\mathrm{K}$ at an improper ratio can result in high dry matter production but not better harvest index. The order of nutrient requirement in the present investigation was $\mathrm{K}>\mathrm{N}>\mathrm{P}$. The requirement of $\mathrm{K}_{2} \mathrm{O}$ was 1.31 times higher than $\mathrm{N}$ and 2.89 times higher than $\mathrm{P}_{2} \mathrm{O}_{5}$. Similar trend of nutrient requirement for $\mathrm{N}, \mathrm{P}_{2} \mathrm{O}_{5}$ and $\mathrm{K}_{2} \mathrm{O}$ was also reported by Verma et al., (2017) for mustard and Santhi et al., (1999) for rice. Experiments conducted at Coimbatore have shown that under the same nutrient application level, SRI plants take up more nutrients and produce more grain weight per unit of nutrient uptake (Thiyagarajan and Biksham Gujja, 2013) This nutrient recovery by the plant is due to extensive root systems of SRI plants which remove more nutrients from the soil.

Per cent contribution of nutrients from soil, fertilizer and FYM

In the present study, it was found that the soil 
has contributed 16.14 per cent of available $\mathrm{N}$, 38.40 per cent of available $\mathrm{P}$ and 16.57 per cent of available $\mathrm{K}$ respectively towards the total $\mathrm{N}, \mathrm{P}$ and $\mathrm{K}$ uptake by rice. Among the three nutrients, the per cent contribution from soil was found to be higher for $\mathrm{P}$ followed by $\mathrm{K}$ and $\mathrm{N}$. With regard to $\mathrm{N}$ and $\mathrm{K}_{2} \mathrm{O}$, comparatively lower $\mathrm{Cs}$ was recorded which might be due to the preferential nature of rice towards the applied $\mathrm{N}$ and $\mathrm{K}_{2} \mathrm{O}$ than the native $\mathrm{N}$ and $\mathrm{K}$.

The per cent contribution from fertilizer nutrients $(\mathrm{Cf})$ towards the total uptake by rice was $35.70,33.17$ and 60.17 per cent, respectively for $\mathrm{N}, \mathrm{P}_{2} \mathrm{O}_{5}$ and $\mathrm{K}_{2} \mathrm{O}$ and followed the order of $\mathrm{K}_{2} \mathrm{O}>\mathrm{N}>\mathrm{P}_{2} \mathrm{O}_{5}$. The per cent contribution of nutrients from fertilizers (Cf) to total uptake followed the order of $\mathrm{K}_{2} \mathrm{O}$ $>\mathrm{N}>\mathrm{P}_{2} \mathrm{O}_{5}$ as that of nutrient requirement. The study clearly revealed the fact that the magnitude of contribution by fertilizer $\mathrm{K}_{2} \mathrm{O}$ was 1.69 times higher than $\mathrm{N}$ and 1.81 times as that of $\mathrm{P}_{2} \mathrm{O}_{5}$. With regard to $\mathrm{N}$ and $\mathrm{K}_{2} \mathrm{O}$, comparatively more contribution was recorded from fertilizers than from the soil. However, in the case of $\mathrm{P}_{2} \mathrm{O}_{5}$, the contribution was more from soil than from fertiliser.

The estimated per cent contribution of $\mathrm{N}, \mathrm{P}_{2} \mathrm{O}_{5}$ and $\mathrm{K}_{2} \mathrm{O}$ from FYM (Cfym) was 24.24, 9.52 and 33.89 respectively for rice which indicated that relatively higher contribution was recorded for $\mathrm{K}_{2} \mathrm{O}$ followed by $\mathrm{N}$ and $\mathrm{P}_{2} \mathrm{O}_{5}$ for rice. The response yardstick recorded was $79.71 \mathrm{~kg} \mathrm{~kg}^{-1}$. The contribution of nutrients from FYM for rice also followed the order as: $\mathrm{K}>\mathrm{N}>\mathrm{P}$ indicated that relatively higher contribution was recorded for $\mathrm{K}_{2} \mathrm{O}$ followed by $\mathrm{N}$ and $\mathrm{P}_{2} \mathrm{O}_{5}$. The present findings were corroborated with the findings of Santhi et al., (1999) in rice and Sellamuthu et al., (2016) in rainfed maize.

Fertilizer prescription equations for rice (rabi season)

Soil test based fertilizer prescription equations for desired yield target of rice for rabi season were formulated using the basic parameters and are furnished below:

\begin{tabular}{llll}
\hline \multirow{2}{*}{ STCR-NPK alone } & \multicolumn{2}{l}{$\begin{array}{l}\text { STCR-IPNS } \\
(\text { NPK + FYM })\end{array}$} \\
\hline $\mathrm{FN}$ & $=4.20 \mathrm{~T}-0.45 \mathrm{SN}$ & $\mathrm{FN}$ & $=4.20 \mathrm{~T}-0.45 \mathrm{SN}-0.68 \mathrm{ON}$ \\
$\mathrm{FP}_{2} \mathrm{O}_{5}=2.05 \mathrm{~T}-2.65 \mathrm{SP}$ & $\mathrm{FP}_{2} \mathrm{O}_{5} \quad=2.05 \mathrm{~T}-2.65 \mathrm{SP}-0.66 \mathrm{OP}$ \\
$\mathrm{FK}_{2} \mathrm{O}$ & $=2.85 \mathrm{~T}-0.29 \mathrm{SK}$ & $\mathrm{FK}_{2} \mathrm{O}=2.85 \mathrm{~T}-0.29 \mathrm{SK}-0.59 \mathrm{OK}$ \\
\hline
\end{tabular}

where, $\mathrm{FN}, \mathrm{FP}_{2} \mathrm{O}_{5}$ and $\mathrm{FK}_{2} \mathrm{O}$ are fertilizer $\mathrm{N}$, $\mathrm{P}_{2} \mathrm{O}_{5}$ and $\mathrm{K}_{2} \mathrm{O}$ in $\mathrm{kg} \mathrm{ha}^{-1}$, respectively; $\mathrm{T}$ is the yield target in $\mathrm{q} \mathrm{ha}^{-1}$; $\mathrm{SN}, \mathrm{SP}$ and $\mathrm{SK}$ respectively are alkaline $\mathrm{KMnO}_{4}-\mathrm{N}$, Olsen-P and $\mathrm{NH}_{4} \mathrm{OAc}-\mathrm{K}$ in $\mathrm{kg} \mathrm{ha}^{-1}$ and $\mathrm{ON}$, OP and $\mathrm{OK}$ are the quantities of $\mathrm{N}, \mathrm{P}$ and $\mathrm{K}$ in $\mathrm{kg} \mathrm{ha}^{-1}$ supplied through FYM.

Table.1 Nutrient requirement, per cent contribution of nutrients from soil, fertilizer and FYM for rice (rabi)

\begin{tabular}{|l|c|c|c|}
\hline \multicolumn{1}{|c|}{ Parameters } & \multicolumn{3}{c|}{ Basic data } \\
\cline { 2 - 4 } & $\mathbf{N}$ & $\mathbf{P}_{\mathbf{2}} \mathbf{O}_{\mathbf{5}}$ & $\mathbf{K}_{\mathbf{2}} \mathbf{O}$ \\
\hline Nutrient requirement $\left(\mathrm{kg} \mathrm{q}^{-\mathbf{- 1}}\right)$ & 1.50 & 0.68 & 1.97 \\
\hline Per cent contribution from soil & 16.14 & 38.40 & 16.57 \\
\hline Per cent contribution from fertilizers & 35.70 & 33.17 & 69.16 \\
\hline Per cent contribution from FYM $\left(\mathbf{C}_{\mathbf{f y m}}\right)$ & 24.24 & 9.52 & 33.89 \\
\hline
\end{tabular}


Table.2 Initial soil available NPK, yield and NPK uptake by rabi rice $\left(\mathrm{kg} \mathrm{ha}^{-1}\right)$

\begin{tabular}{|l|c|c|c|c|c|c|}
\hline $\begin{array}{c}\text { Parameters } \\
\left(\mathrm{kg} \mathrm{ha}^{-1}\right)\end{array}$ & \multicolumn{2}{|c|}{ Strip I } & \multicolumn{2}{c|}{ Strip II } & \multicolumn{2}{c|}{ Strip III } \\
& Range & Mean & Range & Mean & Range & Mean \\
\hline KMnO$_{4}-\mathbf{N}$ & $224-235$ & 230 & $255-266$ & 262 & $290-300$ & $\mathbf{2 9 6}$ \\
\hline Olsen-P & $15.0-20.4$ & 18.0 & $25.5-33.3$ & 30.3 & $33.7-43.4$ & $\mathbf{3 8 . 5}$ \\
\hline $\mathbf{N H}_{\mathbf{4}} \mathbf{O A c}-\mathrm{K}$ & $502-549$ & 539 & $570-595$ & 588 & $601-627$ & $\mathbf{6 2 0}$ \\
\hline Grain yield & $2680-6830$ & 5156 & $2820-7010$ & 5490 & $2900-7440$ & $\mathbf{5 7 3 3}$ \\
\hline N uptake & $39.0-102.6$ & 79.4 & $40.0-124.0$ & 90.5 & $41.8-120.0$ & $\mathbf{9 0 . 3}$ \\
\hline P uptake & $6.2-20.8$ & 14.0 & $9.9-22.4$ & 17.3 & $15.0-24.7$ & $\mathbf{1 9 . 3}$ \\
\hline K uptake & $\mathbf{6 2 . 0 - 1 0 7 . 6}$ & $\mathbf{8 6 . 5}$ & $\mathbf{6 4 . 0 - 1 0 8 . 5}$ & $\mathbf{9 1 . 7}$ & $\mathbf{7 0 . 0 - 1 1 7}$ & $\mathbf{9 5 . 5}$ \\
\hline
\end{tabular}

Table.3 Soil test based fertilizer prescription for yield targets rice 7 and $8 \mathrm{tha}^{-1} \quad\left(\mathrm{~kg} \mathrm{ha}^{-1}\right)$

\begin{tabular}{|c|c|c|c|c|c|c|c|c|c|c|c|c|c|c|}
\hline \multirow{2}{*}{\multicolumn{3}{|c|}{$\begin{array}{l}\text { Soil test values } \\
\left(\mathrm{kg} \mathrm{ha}^{-1}\right)\end{array}$}} & \multicolumn{6}{|c|}{ NPK alone } & \multicolumn{6}{|c|}{ NPK +FYM @ $12.5 \mathrm{t} \mathrm{ha}^{-1}$} \\
\hline & & & \multicolumn{3}{|c|}{$\begin{array}{l}7 \\
\left(\mathrm{tha}^{-1}\right)\end{array}$} & \multicolumn{3}{|c|}{$\begin{array}{l}8 \\
\left(\mathrm{t} \mathrm{ha}^{-1}\right)\end{array}$} & \multicolumn{3}{|c|}{7} & \multicolumn{3}{|c|}{8} \\
\hline SN & SP & SK & FN & $\mathrm{FP}_{2} \mathrm{O}_{5}$ & $\mathrm{FK}_{2} \mathrm{O}$ & FN & $\mathrm{FP}_{2} \mathrm{O}_{5}$ & $\mathrm{FK}_{2} \mathrm{O}$ & $\mathbf{F N}$ & $\mathrm{FP}_{2} \mathrm{O}_{5}$ & $\mathrm{FK}_{2} \mathrm{O}$ & FN & $\mathbf{F P}_{2} \mathbf{C}$ & $\mathrm{FK}_{2} \mathrm{O}$ \\
\hline 200 & 18 & 300 & 204 & 96 & 100 & 246 & 100 & 100 & 164 & 76 & 81 & 206 & 96 & 100 \\
\hline 220 & 20 & 350 & 195 & 91 & 98 & 237 & 100 & 100 & 155 & 71 & 66 & 197 & 91 & 95 \\
\hline 240 & 22 & 400 & 186 & 85 & 84 & 228 & 100 & 100 & 146 & 65 & 52 & 188 & 86 & 80 \\
\hline 260 & 24 & 450 & 177 & 80 & 69 & 219 & 100 & 98 & 137 & 60 & 37 & 179 & 80 & 66 \\
\hline 280 & 26 & 500 & 168 & 75 & 55 & 210 & 95 & 83 & 128 & 55 & 25 & 170 & 75 & 51 \\
\hline 300 & 28 & 550 & 159 & 69 & 40 & 201 & 90 & 69 & 119 & 49 & 25 & 161 & 70 & 37 \\
\hline 320 & 30 & 600 & 150 & 64 & 25 & 192 & 85 & 54 & 110 & 44 & 25 & 152 & 65 & 25 \\
\hline
\end{tabular}

Fertilizer prescription under IPNS for desired yield target of rice

Fertilizer doses for desired yield target of 7 and $8 \mathrm{tha}^{-1}$ of rabi rice were worked out for a range of soil test values and ready reckoner was prepared. For achieving an yield target of $8 \mathrm{t} \mathrm{ha}^{-1}$ of grain yield with a soil test value of 280, 28 and $500 \mathrm{~kg} \mathrm{ha}^{-1}$ of $\mathrm{KMnO} 4-\mathrm{N}$, Olsen$\mathrm{P}$ and NH4OAc-K, the fertilizer $\mathrm{N}, \mathrm{P}_{2} \mathrm{O}_{5}$ and $\mathrm{K}_{2} \mathrm{O}$ doses required were 168,69 and $55 \mathrm{~kg}$ $\mathrm{ha}^{-1}$, respectively under NPK alone and 128, 49 and $25 \mathrm{~kg} \mathrm{ha}^{-1}$ under IPNS

Using the fertilizer prescription equations under IPNS, the extent of saving of chemical fertilizers for rabi rice was computed. The results showed that with the application of FYM @ $12.5 \mathrm{t} \mathrm{ha}^{-1}$ (with 28\% moisture, 0.65, 0.33 and $0.60 \%$ NPK respectively), there was a saving of 40,20 and $32 \mathrm{~kg}$ of fertilizer $\mathrm{N}$, $\mathrm{P}_{2} \mathrm{O}_{5}$ and $\mathrm{K}_{2} \mathrm{O}$ respectively. The NPK fertilizers requirement decreased under IPNS and also with increasing soil fertility levels with reference to NPK and increased with increase in yield targets. These could be achieved by integrated use of FYM with NPK fertilizers. The role of FYM is multidimensional ranging from building up of organic matter, maintaining favourable soil physical properties, priming effect and balanced supply of nutrients. 
The supremacy of fertilizer recommendations based on inductive approach, a refined method of fertilizer recommendation for varying soil test values to obtain higher response ratios and benefit:cost ratios over a wide range of agro-ecological regions in different crops has been highlighted by Dey (2015). From the ready reckoner farmers can choose the desired yield targets according to their investment capabilities and availability of organic manures.

In conclusion, in the present STCR-IPNS based investigation, fertilizer prescription equations were developed for rice (rabi season) under SRI on Typic Haplustalf considering the nutrient requirement, percentage contribution of nutrients from soil, fertilizer and FYM towards total uptake. Targeted yield equations generated from STCR-IPNS technology envisages a balanced nutrient supply to rice and ensures not only sustainable crop production but also economise the use of costly fertilizer inputs. Hence, practice of fertilizing crops using fertilizer prescription equations needs to be popularized among farmers to achieve higher productivity, nutrient use efficiencies and profitability.

The fertilizer prescription equations developed using this model can be applied to Alfisols of all tropical regions by substituting the soil nutrient status of the particular field. Moreover, the methodology adopted in the present investigation viz., the prescription procedure outlined by Truog (1960) and modified by Ramamoorthy et al., (1967) as "Inductive cum Targeted yield model" can very well be used to derive fertilizer prescription equations for any field or horticultural crop on any soil series. Adoption of fertilizer prescription equations along with integrated plant nutrition system and management strategies would enhance the input use efficiency and crop productivity.

\section{Acknowledgement}

The authors gratefully acknowledge the Indian Council of Agricultural Research, New Delhi and Indian Institute of Soil Science, Bhopal and Tamil Nadu Agricultural University, Coimbatore for funding and implementing the All India Coordinated Research Project for Investigations on Soil Test Crop Response Correlation (AICRP-STCR) at Tamil Nadu Agricultural University, Coimbatore.

\section{References}

Antaryami Mishra., B. B. Dash, S. K. Nanda, D. Das and Pradip Dey. 2013. Soil Test Based Fertilizer Recommendation for Targeted Yield of Tomato (Lycopersicon esculentum) under RiceTomato Cropping System in an Ustochrept of Odisha. Environment \& Ecology 31 (2A): 655-658

Dey.P. 2015. Soil Test Crop Response: What Can Be Learnt? In Book of extended summaries. National Dialogue on Efficient Nutrient Management for Improving Soil Health, September 2829, 2015, New Delhi, India conducted by TAAS, ICAR, CIMMYT, IPNI, CSISA, FAI, p. 56. (Eds) Jat, M.L., K. Majumdar, A. McDonald, A.K. Sikka and R.S. Paroda.

Humphries, EC. 1956. Mineral components and ash analysis. Book: Modern methods of plant analysis. Springer Verlag, Berlin 1: 468-562.

Jackson, ML. 1973. Book: Soil chemical analysis. Prentice Hall of India Private Ltd., New Delhi. pp.498.

Mahajan,G.R., R.N. Pandey, S.C. Datta, R.N. Dinesh Kumar, Sahoo and Rajender Parsad. 2013. Soil test based fertilizer recommendation of nitrogen, phosphorus and sulphur in wheat (Triticum aestivum L.) in an alluvial 
soil. International Journal of Agriculture, Environment \& Biotechnology, 6(2): 271-281.

Mahender Kumar, R., P. Raghuveer rao, N. Somasekhar, K. Surekha, CH. Padmavathi, Srinivas Prasad, V. Ravindra Babu, L.V. Subba Rao, P.C. Latha, B. Sreedevi, S. Ravichandran, A.S. Ramprasad, P. Muthuraman, S. Gopalakrishnan, V. Vinod Goud and B.C. Viraktamath. 2013. SRI-A method for sustainable intensification of rice production with enhanced water productivity. Agrotechnol, (11 ) 1-6

Olsen, S.R., C.V. Cole, F.S. Watanabe and L. Dean. 1954. Estimation of available phosphorus in soils by extraction with sodium bicarbonate. U.S.D.A. Circ. 939. U.S. Govt. Printing Office, Washington, DC.

Ramamoorthy, B., R.K.Narasimham, R.S. Dinesh. 1967. Fertiliser application for specific yield targets on Sonora 64 (wheat). Indian Fmg 17: 43-45.

Santhi, R, G. Selvakumari and Rani Perumal. 1999. Soil test based fertiliser recommendations under Integrated Plant Nutrition System for rice-rice-pulse cropping sequence. J. Indian Soc. Soil Sci. 47(2):288-294.

Santhi, R., K.M. Sellamuthu, S. Maragatham, R. Natesan, K. Arulmozhiselvan, K. Kumar, and P. Dey. 2017. "Soil Test and Yield Target based Fertiliser Prescriptions for Crops - An Overview of Outreach Activities in Tribal villages of Tamil Nadu" (in Tamil), AICRP-
STCR, Department of Soil Science and Agricultural Chemistry, Tamil Nadu Agricultural University, Coimbatore 641 003. TNAU Offset \& Printing Press, Coimbatore.

Saraswathi, Y., Vishawanath Shetty, Ashwini, M. Nethravathi and S. Vandana. 2015. Studies on feasibility and response of NPK application through different approaches in ragi under rainfed condition, The Ecoscan, 7,349-353.

Sellamuthu,K.M., R.Santhi, S.Maragatham and P. Dey.2016. Soil test and yield target based balanced fertilizer prescription for rainfed maize on an alfisol. Res. on Crops 17 (2): 231-239 (2016)

Stanford, S. and L.English (1949). Use of flame photometer in rapid soil tests of $\mathrm{K}$ and Ca. Agron J 41: 446

Subbiah, B.V. and G.L. Asija. 1956. A rapid procedure for the estimation of available nitrogen in soils. Curr Sci 25: 259-260.

Thiyagarajan T.M and Biksham Gujja. 2013. Transforming rice production with SRI (System of Rice Intensification) knowledge and practice. Nationa consortium on SRI (NCS). PP. 92

Truog, E.1960. Fifty years of soil testing. Trans $7^{\text {th }}$ Intl. Congr. Soil Sci. Vol. III Commission IV paper No.7: pp: 46-53.

Verma, M., Y.V.Singh, P. Dey and A. Babu. 2017. Soil Test based Fertilizer Recommendation for Mustard (Brassica juncea L.) in Eastern Plain Zone of Uttar Pradesh, India. Int.J.Curr. Microbiol.App.Sci., 6(2): 155-161

\section{How to cite this article:}

Maragatham, S., Santhi, R., Sellamuthu, K.M. and Pradip Dey. 2018. Yield Targeting for Rice under SRI on Alfisols of Tamil Nadu through Soil Test based Integrated Plant Nutrition System. Int.J.Curr.Microbiol.App.Sci. 7(08): 1134-1143. doi: https://doi.org/10.20546/ijcmas.2018.708.129 